\title{
Scientometric analysis of Colombian research on bio-inoculants for agricultural production
}

\author{
Diana Corina Zambrano-Moreno, ${ }^{1, *}$, Laura Avellaneda-Franco ${ }^{2}$, \\ Gregorio Zambrano ${ }^{2}$, Ruth Rebeca Bonilla-Buitrago ${ }^{2}$
}

\author{
Edited by \\ Juan Carlos Salcedo-Reyes \\ (salcedo.juan@javeriana.edu.co) \\ 1. Instituto Tecnológico de Costa Rica, \\ School of Biology, Cartago 30101, \\ Costa Rica. \\ 2. Corporación Colombiana \\ de Investigación Agropecuaria \\ CORPOICA. \\ *corina_zambrano@yahoo.es \\ Received: 11-02-2015 \\ Accepted: 13-11-2015 \\ Published on line: 26-02-2016 \\ Citation: Zambrano-Moreno DC, \\ Avellaneda-Franco L, Zambrano G, \\ Bonilla-Buitrago RR. Scientometric \\ analysis of Colombian research on \\ bio-inoculants for agricultural \\ production, \\ Universitas Scientiarum, 21 (1): 63-81, 2016. \\ doi: 10.11144/Javeriana.SC21-1.saoc \\ Funding: N/A \\ Electronic supplementary material: \\ $\mathrm{N} / \mathrm{A}$ \\ OPEN ACCESS
}

\section{Abstract}

The excessive use of synthetic chemical inputs in agricultural production has led to the disruption of biogeochemical cycles. One of the alternatives that arose within the systems of sustainable agriculture was the partial or total replacement of chemicals by biological substances. The analysis of relevant scientific literature has become a tool for assessing the quality of knowledge generation and its impact on the environment. A scientometric analysis was conducted of Colombian research on bio-inoculants from 2009 through 2014 in journals added to the Web of Sciences ${ }^{\mathrm{TM}}$ in order to identify the characteristics of the main target crops, the microorganisms used, and the beneficial effects on agriculture. In this work, 34 articles were identified: $24(71 \%)$ were research on bio-fertilizer development and $10(29 \%)$ on biopesticides. Articles mainly focused on the study of Gram-negative bacilli affecting the area $(77 \%)$, while others focused on issues and topics surrounding vegetables (30\%).The analysis of co-occurrence of keywords identified: i. several genera of microorganisms (e.g. Azotobacter sp., Bradyrbizobium sp.) and sustainable agriculture as issues that have a leading role in this scientific field, ii. plant growth promoting rhizobacteria (PGPR) as an emerging issue, iii. biological nitrogen fixation (BNF) as a subject which has risen in a complementary manner and iv. endophytic bacteria and biodiversity as issues in growth. This study showed that research in Colombia could be targeted on issues such as endophytic bacteria, diversity and productivity.

Keywords: Bioinoculants, scientometrics, microbial inoculants, sustainable development.

\section{Introduction}

The world's population is expected to grow from 6.8 billion to 9.1 billion by 2050 . Feeding these people would be easy if natural resources, such as land and water, were inexhaustible (Godfray et al. 2010). However, resources are limited and to continue with environmentally destructive agriculture and livestock farming is a poor option. The intensive use of chemical inputs in agricultural production has led to a disruption of biogeochemical cycles. Moreover, agriculture and livestock contribute to climate change by releasing greenhouse gases such as nitrous oxide, mainly due to organic 
nitrogen fertilizers and methane from the Ruminant's digestion processes and storage of animal manure. Paradoxically, agricultural productivity is very sensitive to climate change (Hatfield et al. 2011). These issues generate a challenge to ensure food security in the world.

According to Sanjuán \& Moreno (2010), reevaluating agricultural practices to improve their productivity of feeding billions of people worldwide without damaging the soil is made possible by biotechnology techniques and the use of microorganisms. Agricultural microbiology is a field responsible for the transfer of knowledge from general microbiology and microbial ecology to agricultural biotechnology research. (Tikhonovich \& Provorov 2011). Within the scope of agricultural microbiology is the production of bio-inoculants with standards of quality and efficiency that improve yield of crops.

In the last two decades, the use of microbial inoculants in agriculture and agricultural research in the public and private sector have increased (Hayat et al. 2010) in the search for solutions that contribute to the sustainable intensification of agriculture. The bio-inoculants mainly include free-living bacteria, fungi, and arbuscular mycorrhizal fungi (AMF) (Dodd \& Ruiz-Lozano 2012) which are isolated from a variety of environments including soil, plants, and waste (e.g. water and composted manure). Among the bio-fertilizers that have been studied in depth are the plant growth promoting rhizobacteria (PGPR). The bio-inoculants are classified as bio control agents (also called bio-pesticides) and bio-fertilizers (Bashan \& Holguin 1998).

The bio-fertilizer or biological products containing live microorganisms that, when applied to the surface of the seed, plants, or soil promotes plant growth by various mechanisms, such as increased nutrient supply, increased biomass or root area, and increased nutrient uptake ability by the plant (Vessey 2003). Also, microorganisms are able to mitigate the impact of abiotic stresses (salinity, drought and acidity) on the plant (Cheng et al. 2007).

The research and policies supporting sustainable agricultural production have improved the efficiency and quality of microbial inoculants by influencing the creation of the commercial register of several products based on microorganisms; both for biological control as biofertilization with mycorrhizae and PGPR preparations that are commercially available in several countries. However, the spreading use of microbial inoculants, especially those who act like phytostimulants or bio-fertilizers, have been hampered due to their variability and inconsistent results obtained in laboratory, greenhouse, and field. Moreover, the lack of adequate formulations and the long commercial registration process are among the factors that limit the use of bio-inoculants on a wider scale (Malus et al. 2012) and restricts the bio-inoculant's potential as an important tool in the sustainable intensification of agriculture.

In general, crop response to inoculation with PGPR may be affected and present differences between the results of laboratory and field applications because after the suspensions of microorganisms are inoculated into the soil without adequate support, the bacterial population decreases rapidly. This phenomenon is due, according to Bashan et al. (2014), to the inherent heterogeneity of the soil; the main obstacle to the introduction of PGPR. Unprotected inoculated microorganisms 
must compete with better adapted native microflora and maintain the enzyme activity in the rhizosphere under conditions not corresponding to their optimal growth temperature. Consequently, an important part of the formulation of inoculants is to provide an adequate number of microorganisms combined with physical protection to prevent rapid decrease down PGPR introduced.

One key tool to guarantee the quality of bio-inoculants is the analysis of scientific publications about their development because this allows assess to its coherence and statistical support of the process, and its impact on the environment (Rueda-Clausen et al. 2005). The aim of this study was to identify the characteristics of bio-inoculants as main target crops, their microorganisms used, and the beneficial effects on the Colombian Agriculture by mean of a scientometric analysis of research on bio-inoculants during the years 2009 through 2014 in journals indexed in Science Citation Index Expanded, Social Sciences Citation Index, Arts \& Humanities Citation Index, KCI-Korean Journal Database and Scielo Citation Index.

\section{Methodology}

Type of study

A descriptive scientometric study was carried out, through the review of original articles published about bio-inoculants by Colombian authors during the years 2009 to 2014 indexed in the principal collection of the Web of ScienceTM (WoS) from Thomson Reuters Institute of Scientific Information (ISI) that includes the subscribed databases Science Citation Index Expanded, Social Sciences Citation Index, Arts \& Humanities Citation Index, KCI-Korean Journal Database and Scielo Citation Index.

\section{Materials analysis and its origin}

\section{Search criteria}

In this study, the search terms used in the basic-research field were: promoting rhizobacteria, nitrogen fixation, bio-fertilizer, bio-inoculants, bio-pesticides and biological control. The search was for articles published between 2009 and 2014, without making any topic filter. Studies published in English, Spanish, and Portuguese were consulted. Only original research articles where at least one of the authors was affiliated to a Colombian institutions were considered in the scientometric analysis, due to the inclusion of non-original papers (grey literature) analysis could generate bias in the study (Perez et al. 2002). Original articles were considered as those who contribute original results (i.e. those that have not been published previously) have evaluated by scientific peers, and have the typical structure of introduction, materials and methods, results, discussion, and references (Villar et al. 2007).

The aforementioned search criteria was entered into the WoS showing a total of 14429 documents. The process of refining the search filter was applied exclusively to present original articles and found 12792 items. Then, it was refined by country, where 414 documents were obtained and examined. Only 34 articles were selected, taking into account the definition of "bioinsumo" (i.e. defined by the Instituto Colombiano Agropecuario (ICA) as a substance or mixture of substances made of organic or 
natural, sustainable and safe source.) Only bio-inoculants with microorganisms as active principle were included, namely biological inoculants and biological control agents. We excluded articles in which the organism was isolated from waste because the safety of the microorganism is not guaranteed. Additionally, the microorganism used and research should be obtained from different ecosystems from Colombia because it was in our interest to review the use of the native biodiversity and their use in agricultural production.

\section{Data collection and processing}

The obtained information was organized in a two-way table on Microsoft Excel (2013) to control the quality. In these tables; the title, journal name, language, names of authors, year of publication, keywords, and abstract are registered. Subsequently, 34 articles were read in full to supplement the Excel database with information such as objective plant, used microorganisms, biological activities tested, and the beneficial effect of obtained results in the agriculture. This information was used to generate descriptive analysis.

\section{Analysis of co-occurrence}

The co-occurrence analysis is a method that identifies the most frequently associated words contained in the scientific publications in a database (Solleiro, 2002). From the generated Excel database, we extracted an $m \times n$ matrix where $m$ is the number of keywords analyzed, and $\mathrm{n}$ is the number of keywords (matrix keyword-article) (i.e. applying the methodology described by Vargas \& Castellanos (2005)).

The matrix was normalized by calculating Jaccard index (Pelc 2000), which is defined by Equation 1 .

$$
\mathrm{J}(i j)=\frac{C_{i j}}{C_{i}+C_{j}-C_{i j}}
$$

Where: $C_{i j}$ is the number of occurrences of the words $i$ and $j, C_{i}$ frequency of word $i$ and $C_{j}$ word frequency $j$.

From the results obtained using the Jaccard index, a multidimensional scaling technique was used. This technique generates a two-dimensional graph representing the numerical relation between different variables found in the $42 \times 42$ matrix obtained from the keywords (Cox \& Cox 2001). The horizontal and vertical axis of the graph represents the centrality and the density, respectively. A strategic diagram was created using the SPSS 21.0 software with the information of the matrix.

The strategic plot was interpreted as Longar \& Rivers (2014) suggested; based on the appearance of words in each quadrant of the Cartesian axis, as shown in Figure 1.

- First quadrant (located at the above right): the topics are characterized by main issues and high development. Also, the topics are supported by well-structured research groups, which play a driving role in the evaluated scientific field. 


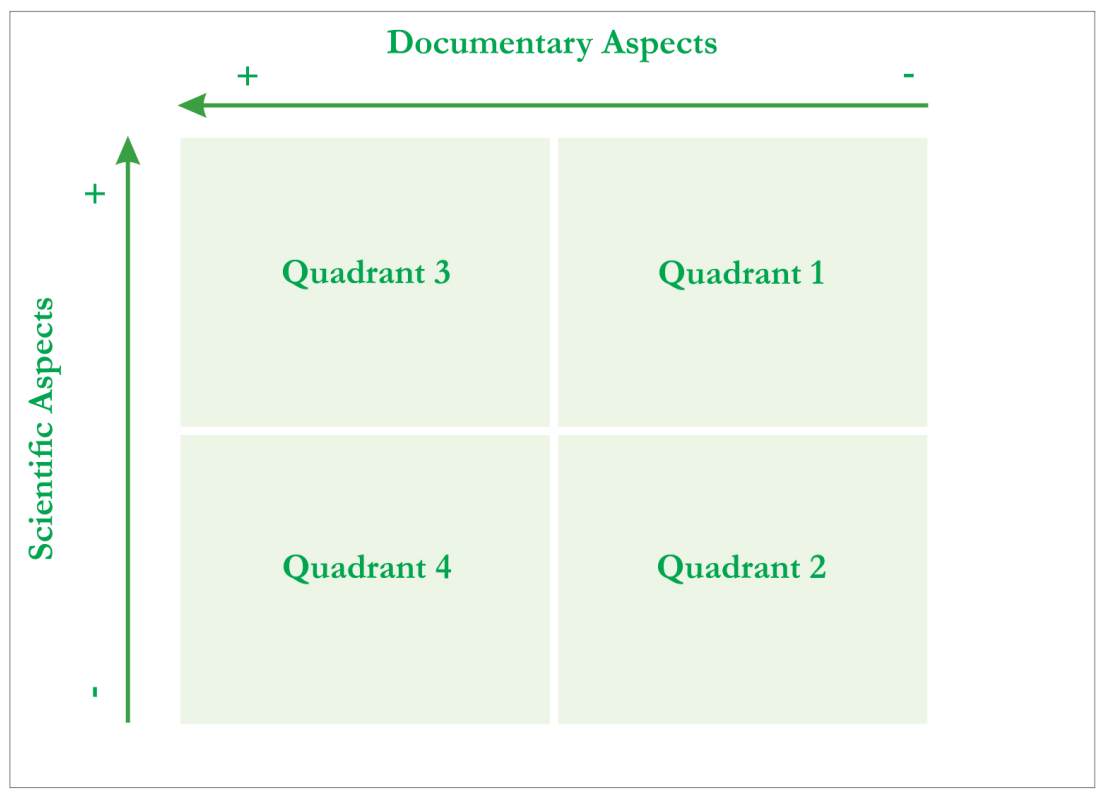

Fig. 1. Position of the quadrants in the strategic diagram.

- Second quadrant (located at the bottom right): Presents the topics considered well-connected but underdeveloped; these can be seen as emerging or bridge issues.

- Third quadrant (located at the top left): the topics are considered as representative of a highly specialized with a high activity, but these are isolate or in peripheral fields of scientific study; are subjects of other fields of study who venture into it.

- Fourth quadrant (located at the bottom left shows): the topics that appeared for the first time and in many cases definitely disappear; this includes underdeveloped peripheral topics.

\section{Results and discussion}

The search on WoS with the above mentioned criteria showed a total of 14429 documents (Table 1) of which 12792 corresponded to original articles. Only $3.24 \%$ $(414 / 12792)$ of the original articles found have at least one author with Colombian

Table 1. Search results in number of articles.

\begin{tabular}{lrrrrr}
\hline Search terms & \multicolumn{1}{c}{ Total } & Article & $\begin{array}{c}\text { Colombian } \\
\text { articles }\end{array}$ & $\begin{array}{c}\text { \% Colombian } \\
\text { articles }\end{array}$ & $\begin{array}{c}\text { Selected } \\
\text { articles }\end{array}$ \\
\hline Promoting bacteria & 1603 & 1432 & 35 & 2.44 & 4 \\
Nitrogen fixation & 5858 & 5316 & 36 & 0.68 & 15 \\
Biofertilizer & 557 & 532 & 11 & 2.07 & 3 \\
Bioinoculants & 80 & 78 & 3 & 3.85 & 2 \\
Biopesticides & 752 & 628 & 21 & 3.34 & 2 \\
Biological control & 5579 & 4806 & 308 & 6.41 & 8 \\
& 14429 & 12792 & 414 & 3.24 & 34 \\
\hline
\end{tabular}


affiliation. According to this result, the Colombian scientific production is barely visible, similar to the result found between 1995 and 2007 by Baquero et al. (2007); a total of 15 Colombian articles indexed in standard journals.

414 original articles were found with membership to Colombian institutions. However, after review and application of the search criteria, 34 original articles were obtained that it were included in this study. The results of searching on WoS found 34 Colombian authors published between 2009 and 2014. Twenty four articles $(71 \%)$ were investigated for the development of bio-fertilizers and ten $(29 \%)$ for bio-pesticides. During the period between 1996 and 2007, Baquero et al. (2007) reported that Colombia had 15 publications on bio-inoculants, specifically on biological control and insects, contrary to what was seen in recent years, where the trend of research has been directed towards the issue of bio-fertilizers.

Ten of the Colombian articles were published in 2014, seven in 2013, two in 2012, six in 2011, six in 2010, and three in 2009. The annual frequency of publication shows a growing trend since 2009. This increase is consistent with research done by Baquero et al. (2007), who identified that publications related to the topic of bio-inoculants presented an upward trend on a global scale, with an average of 72 publications, of which the production of Latin American countries reached only $1 \%$ in total.

The journals where the articles were published are showed in Table 2. Ten of eighteen journals are Colombian. It is noteworthy that $74 \%$ of articles were published in the Spanish language; generating that the impact factor of these publication to decline. According to Téllez et al. (2007), an important aspect that reduces the diffusion of Latin American research published in journals is the language of publication.

Table 2. Number of articles published by journal.

\begin{tabular}{lc}
\hline \multicolumn{1}{c}{ Journal } & Number of articles \\
\hline Revista Colombiana de Biotecnología & 5 \\
Acta Biológica Colombiana & 4 \\
Pastos y Forrajes & 3 \\
Universitas Scientiarum & 3 \\
African Journal of Biotechnology & 2 \\
Agronomía Colombiana & 2 \\
Acta Agronómica & 2 \\
Applied Soil Ecology & 2 \\
Revista Facultad Nacional de Agronomía Medellín & 2 \\
Actualidades Biológicas & 1 \\
Bosque & 1 \\
Brazilian Journal of Microbiology & 1 \\
Journal of General Plant Pathology & 1 \\
Plant Soil & 1 \\
Revista Colombiana de Ciencias Químico - Farmacéuticas & 1 \\
Revista Mexicana de Ciencias Agrícolas & 1 \\
Revista Corpoica y Tecnología Agropecuaria & 1 \\
Journal of Visualized Experiments & 1 \\
\hline
\end{tabular}


Application main crops: The advances in bio-inoculants during the period analyzed in the country are mainly focused in vegetables (30\% of articles), followed by research on cereals $(16 \%)$, and herbaceous crops $(14 \%)$. Lesser percentage progress for tree species $(14 \%)$, perennes $(11 \%)$, shrubs $(7 \%)$, tubers $(5 \%)$, and ornamental $(3 \%)$.

The highest percentage in research on vegetables may be given to the issue of organic products, which has had a special interest in growing demand in market segments. The National Horticultural Plan (CCI 2012) argues the sales of organic products in the world are growing between $20 \%$ and $50 \%$ annually, depending on the type of food. This growth is supported by Dias et al. (2013); it has been established as a component of a healthy diet, leading to a growing interest in developing new approaches to improve vegetable production.

Type of microorganisms: Filamentous fungi, mycorrhizal fungi, Gram positive bacilli, and Gram negative bacilli are the more used morphological groups of microorganisms. In the analyzed studies, Gram negative bacilli was predominate with $77 \%$, followed by filamentous fungi at $11 \%$, Gram positive bacilli with $7 \%$, and finally, mycorrhizal fungi with $5 \%$. It is likely that the highest percentage was Gram negative bacilli because in the rhizosphere, Gram negative bacteria predominates with high growth rates (Beneduzi et al. 2012). The most evaluated activity was biological nitrogen fixation. According to Francis et al. (2010), the interaction with the plant has been investigated mainly with Gram negative bacteria because they are easily isolated from the tissues of plants, easy to handle, and susceptible to genetic analysis.

The trend of biological control research showed orientation to filamentous fungi, especially Trichoderma. In efficiency, as biological control of pests and plant pathogens, Trichoderma has been studied extensively on the benefits for farmers and its ability to protect the environment (Cuevas et al. 2013). However, in recent years, an increase in studies regarding the characteristics of Trichoderma have risen out of concern about the risks of introducing an invasive alien species to environmental biodiversity is widely recognized. Due to the high reproductive rate of Trichoderma sp., the strains that have not been introduced from other countries can do parasitism or predation by non-target species, competition, and movement of species or disturbance of the functions of native ecosystems.

Beneficial effect on agriculture: The development and use of bio-inoculants based microbes has been increasing worldwide due to the recognition of the harmful effects on the environment of excessive or inappropriate use of chemical inputs and the requirement of strategies to feed the world's population by 2050 with sustainable agriculture. Also, the newest technologies used to perform experiments to understand the relation and the interaction between the plants, soil, and microorganisms that occur in the rhizosphere (Malusá \& Vassiley 2014) are an important tool to improve the formulation of bio-inoculants.

The increase of crop yield or quality caused by bio-inoculants has been linked, in some cases, to the increased availability and uptake of nutrients, particularly biological nitrogen fixation (Table 3). For example, Valencia \& Ligarreto (2010) reported that some soybean varieties showed a positive response with strains of Bradyrbizobium japonicum in oxisols of the Colombian Orinoquia and that the symbiotic relationship and grain yield were somehow affected the most important factors of genotypeenvironment interaction: variety, water shortages, soil compaction and diseases, particularly the presence of Cercospora sojina. 
Table 3. Summary of the articles analyzed and reported profits in agriculture. FBN: Biological Nitrogen Fixation, AIA: production of indole acetic acid.

\begin{tabular}{|c|c|c|c|c|}
\hline Crop & Type microorganism & Activity evaluated & Reference & Beneficial effect on agriculture \\
\hline $\begin{array}{l}\text { Cowpea } \\
\text { (Vigna unguiculata) }\end{array}$ & $\begin{array}{l}\text { Rhizobium sp., } \\
\text { Bradyrbizobium sp. }\end{array}$ & $\begin{array}{l}\text { Antibiotic resistance, } \\
\mathrm{Zn}+2, \mathrm{Al}+2 \text { and } \\
\mathrm{Co}+2, \text { temperature, } \\
\text { and } \mathrm{pH} \text { tolerance, } \mathrm{NaCl} \\
\text { concentrations. }\end{array}$ & Cuadrado et al. 2009 & $\begin{array}{l}\text { Different strains from the } \\
\text { same node show promiscuity } \\
\text { of } V . \text { unguiculata that gives an } \\
\text { advantage over other legume } \\
\text { species. }\end{array}$ \\
\hline $\begin{array}{l}\text { Tomato } \\
\text { (Solanum lycopersicum) }\end{array}$ & Trichoderma koningiopsis & $\begin{array}{l}\text { Biological control of } \\
\text { Fusarium sp. }\end{array}$ & Jaimes et al. 2009 & $\begin{array}{l}\text { Reducing the incidence of neck } \\
\text { rot and roots by } 35 \% \text {, compared } \\
\text { to the absolute control. }\end{array}$ \\
\hline $\begin{array}{l}\text { Patula pine } \\
\text { (Pinus patula) }\end{array}$ & $\begin{array}{l}\text { Azotobacter chroococcum, } \\
\text { Bacillus macerans, } \\
\text { Enterobacter aglomerans, } \\
\text { Pseudomonas sp. and } \\
\text { Suillus luteus }\end{array}$ & FBN & $\begin{array}{l}\text { Orozco \& Martínez } \\
2009\end{array}$ & $\begin{array}{l}\text { Stimulation of longitudinal } \\
\text { growth and improved nitrogen } \\
\text { nutrition of } P \text {. patula. }\end{array}$ \\
\hline $\begin{array}{l}\text { Guinea grass } \\
\text { (Panicum máximum) }\end{array}$ & Azospirillum sp. & FBN, AIA & Cárdenas et al. 2010 & $\begin{array}{l}\text { Arospirillum sp. maintained its } \\
\text { viable population in conditions } \\
\text { of water stress. }\end{array}$ \\
\hline
\end{tabular}

\section{Clover \\ (Trifolium) \\ Actinomycete strains}

\section{Guinea grass, Anglenton grass (Dichanthium aristatum) y Common grazing (Brachiaria decumbens)}

Eucalyptus
(Eucalyptus)

Soybean (Glycine max)

Stevia

(Stevia rebaudiana)

Quickstick

(Gliricidia sepium)

Passion Fruit

(Passiflora edulis) Bradyrbizobium japonicum

Azospirillum sp.,

Herbaspirillum sp.,

Burkholderia sp.,

Gluconacetobacter sp.,

Derxia sp.,

Beijerinckia sp. and

Azotobacter sp.

Beijerinckia sp.,

Azotobacter sp.,Derxia sp.,

Herbarpirillum sp.,

Azospirillum sp.,

Gluconacetobacter sp. and

Burkholderia sp.

Bacillus thuringiensis

Azotobacter nigricans

Rhizobium sp.

Trichoderma harzianum
Solubilizing/mineralizing Francis et al. 2010 sparingly phosphate sources, N2-fixation and/or siderophore production.

Microaerophilic

population diazotrophic and free life

diazotrophic.

FBN, AIA

Obando et al. 2010

Evaluated five bioassay methods measuring three commercial products toxicity on Tuta absoluta larvae

Symbiotic association

Microbiological and physicochemical analysis

Ramirez et al. 2010

Valencia \& Ligarreto 2010

Borda et al. 2011

FBN and AIA

Biocontrol capacity of

T. harzianum Rifai against

Fusarium solani (Mart.).

Cubillos et al. 2011b
Selected actinomycetes improve arbuscular mycorrhizal formation by clover plants and Glomus mosseae.

In times of drought, it reduced the number of bacteria in the roots observed and soil.

The population of the species diazotrophic effect of climatic periods were not affected.

The three commercial products produced high mortality in Lab conditions.

The symbiotic association had gains in grain yield and disease tolerance.

The application of bio-fertilizer showed a positive correlation with mineralization of compost and synthesis of glycosides.

Cubillos et al. 2011a RhizobiolC stimulates growth and development of seedlings. Biocontrol effect of F. solani using concentrations of 106 and 108 conidia/ $\mathrm{mL}$ of both native and commercial strains. 


\begin{tabular}{|c|c|c|c|c|}
\hline Crop & Type microorganism & Activity evaluated & Reference & Beneficial effect on agriculture \\
\hline $\begin{array}{l}\text { Tomato, cabbage } \\
\text { (Brassica oleracea), } \\
\text { carrot (Daucus carota), } \\
\text { spinach (Spinacia } \\
\text { oleracea) and pumpkin } \\
\text { (Cucurbita pepo) }\end{array}$ & A. chroococcum, A. nigricans & $\mathrm{FBN}$ & Jiménez et al. 2011 & $\begin{array}{l}\text { Usefulness of molecular and } \\
\text { Bioinformatics techniques as } \\
\text { tools to support the conventional } \\
\text { techniques of microbial } \\
\text { characterization. }\end{array}$ \\
\hline Pasto & $\begin{array}{l}\text { Klebsiella sp., } \\
\text { Enterobacter sp. and } \\
\text { Micrococcus sp. }\end{array}$ & FBN & Kelemu et al. 2011 & $\begin{array}{l}\text { The total content of } \mathrm{N} \text { in stems } \\
\text { and leaves was significantly } \\
\text { higher in inoculated plants. }\end{array}$ \\
\hline Tomato & Trichoderma koningiopsis & Candidate genes & $\begin{array}{l}\text { Simbaqueba et. al. } \\
2011\end{array}$ & $\begin{array}{l}\text { Candidate genes can be used as } \\
\text { markers for assisted selection of } \\
\text { induced systemic resistance (ISR). }\end{array}$ \\
\hline $\begin{array}{l}\text { Cotton } \\
\text { (Gossypium hirsutum) }\end{array}$ & $\begin{array}{l}\text { Azotobacter sp. and } \\
\text { Azospirillum sp. }\end{array}$ & FBN, AIA & Guzmán et al. 2012 & Promoting plant growth in vitro. \\
\hline $\begin{array}{l}\text { Corn } \\
\text { (Zea mays) }\end{array}$ & A. chroococcum & $\begin{array}{l}\text { FBN, AIA, phosphate } \\
\text { solubilization }\end{array}$ & Rojas et al. 2012 & $\begin{array}{l}\text { Bacteria improved resistance to } \\
\text { salt stress in maize plants. }\end{array}$ \\
\hline $\begin{array}{l}\text { Potato } \\
\text { (Solanum tuberosum) }\end{array}$ & $\begin{array}{l}\text { Community microbiota } \\
\text { rhizosphere }\end{array}$ & Microorganisms N cycle & Flórez et al. 2013 & $\begin{array}{l}\text { Agricultural management } \\
\text { practices governing the } \\
\text { distribution and activity of } \\
\text { functional groups associated } \\
\text { with the nitrogen cycle. }\end{array}$ \\
\hline $\begin{array}{l}\text { Cocoa } \\
\text { (Theobroma cacao L.) }\end{array}$ & $\begin{array}{l}\text { Paecilomyces sp. and } \\
\text { Lecanicillium } \mathrm{sp} .\end{array}$ & $\begin{array}{l}\text { Pathogenicity of native } \\
\text { strains Paecilomyces sp. and } \\
\text { Lecanicillium sp. on larvae } \\
\text { of Carmenta foraseminis }\end{array}$ & Medina et al. 2013 & $\begin{array}{l}\text { The lowest concentration of } \\
\text { inoculum to remove } 50 \text { to } \\
90 \% \text { of the treated population, } \\
\text { indicating it is more effective } \\
\text { against larvae. }\end{array}$ \\
\hline Corn & $\begin{array}{l}\text { Stenotrophomonas } \\
\text { maltophilia and Azotobacter } \\
\text { vinelandii }\end{array}$ & Greenhouse test & $\frac{\text { Moreno \& Galvis }}{2013}$ & $\begin{array}{l}\text { Improved plant emergence, stem } \\
\text { diameter and length of the leaves } \\
\text { and stems. }\end{array}$ \\
\hline $\begin{array}{l}\text { Bean } \\
\text { (Phaseolus vulgaris) }\end{array}$ & Beawveria bassiana & $\begin{array}{l}\text { Evaluations of } \\
\text { endophytic biological } \\
\text { control }\end{array}$ & Parsa et al. 2013 & $\begin{array}{l}\text { Specific outcome may depend on } \\
\text { the target crop species or variety, } \\
\text { the fungal entomopathogen } \\
\text { species strain or isolate used, and } \\
\text { the plant's growing conditions. }\end{array}$ \\
\hline Eucalyptus & $\begin{array}{l}\text { A.chroococcum and } \\
\text { A. vinelandii }\end{array}$ & $\mathrm{FBN}$ & Rojas et al. 2013 & $\begin{array}{l}\text { Lyophilization with S/BSA best } \\
\text { technique for preserving the } \\
\text { viability and activity of the strains. }\end{array}$ \\
\hline $\begin{array}{l}\text { Lettuce } \\
\text { (Lactuca sativa), } \\
\text { Golden berry } \\
\text { (Physalis peruviana) }\end{array}$ & Trichoderma sp. & $\begin{array}{l}\text { Biological control of } \\
\text { Sclerotinia sclerotiorum }\end{array}$ & Smith et al. 2013 & $\begin{array}{l}\text { Prevents } 70 \% \text { germination } \\
\text { of sclerotia of S. sclerotiorum. } \\
\text { In bioassays, no relationship } \\
\text { between the rate of mycelial } \\
\text { growth and parasitism was found. }\end{array}$ \\
\hline Cacao & $\begin{array}{l}\text { Burkbolderia sp., } \\
\text { Gluconacetobacter sp., } \\
\text { Herbaspirillum sp. }\end{array}$ & FBN, biological activity & $\frac{\text { Arguello \& Moreno }}{2014}$ & $\begin{array}{l}\text { Further development in } \\
\text { inoculated plants stem length, } \\
\text { root and leaf blade; and higher } \\
\text { concentration of nitrogen in } \\
\text { plant tissue. }\end{array}$ \\
\hline Guinea grass & $\begin{array}{l}\text { Azospirillum sp., } \\
\text { E. aglomerans }\end{array}$ & Biological activity & Cárdenas et al. 2014 & $\begin{array}{l}\text { Azospirillum sp. co-inoculated } \\
\text { with Enterobacter aglomerans } \\
\text { recorded the highest values in } \\
\text { plant growth. }\end{array}$ \\
\hline Tomato & Candida guilliermondii & $\begin{array}{l}\text { Biological control of } \\
\text { Rhizopus stolonifer in } \\
\text { postharvest tomatoes }\end{array}$ & Celis et al. 2014 & $\begin{array}{l}\text { Increase the shelf life of } \\
\text { tomatoes improving the } \\
\text { distribution of the product and } \\
\text { preventing postharvest losses }\end{array}$ \\
\hline
\end{tabular}




\begin{tabular}{|c|c|c|c|c|}
\hline Crop & Type microorganism & Activity evaluated & Reference & Beneficial effect on agriculture \\
\hline $\begin{array}{l}\text { Chrysanthemum } \\
\text { (Chrysanthemum) }\end{array}$ & Purpureocillium sp. & $\begin{array}{l}\text { Potential control } \\
\text { sypmhylans } \\
\text { (Scutigerella } \mathrm{sp} .)\end{array}$ & Gallego et al. 2014 & $\begin{array}{l}\text { In vitro compatibility with most } \\
\text { biocontrol fungi except } T \text {. viride. }\end{array}$ \\
\hline $\begin{array}{l}\text { Pea } \\
\text { (Pisum sativum) }\end{array}$ & Trichoderma spp. & $\begin{array}{l}\text { Antagonistic capacity to } \\
\text { control of F. oxysporum }\end{array}$ & Insuasty et al. 2014 & $\begin{array}{l}\text { Showed antagonistic activity in } \\
\text { the greenhouse. }\end{array}$ \\
\hline Cowpea & & $\begin{array}{l}\text { FBN, AIA, nodulation } \\
\text { tests }\end{array}$ & $\begin{array}{l}\text { Mendoza \& Bonilla } \\
2014\end{array}$ & $\begin{array}{l}\text { Under greenhouse conditions } \\
\text { the biological fertilization was } \\
\text { more efficient than chemical. }\end{array}$ \\
\hline Soybean, Pea & $\begin{array}{l}\text { Rbizobium sp., } \\
\text { Bradyrbizobium sp. }\end{array}$ & Biological activity & Moreno et al. 2014 & $\begin{array}{l}\text { The temperature did not } \\
\text { affect the survival and rhizobia } \\
\text { concentration after } 180 \text { days } \\
\text { of storage ensuring quality } \\
\text { inoculant. }\end{array}$ \\
\hline Lettuce & $\begin{array}{l}\text { Pseudomonas fluorescens, } \\
\text { Pseudomonas sp. }\end{array}$ & $\begin{array}{l}\text { Solubilization of P, } \\
\text { AIA, synthesis of } \\
\text { siderophores }\end{array}$ & Sánchez et al. 2014a & $\begin{array}{l}\text { Increase biomass and plant } \\
\text { development. }\end{array}$ \\
\hline Golden berry & $\begin{array}{l}\text { Pseudomonas sp., } \\
\text { Bacillus sp. }\end{array}$ & $\begin{array}{l}\text { Root exudates } \\
\text { (malic acid) and AIA }\end{array}$ & Sánchez et al. 2014b & $\begin{array}{l}\text { The strains generated higher } \\
\text { growth promotion under } \\
\text { greenhouse conditions using } \\
50 \% \text { tricalcium phosphate. }\end{array}$ \\
\hline $\begin{array}{l}\text { Rice } \\
\text { (Oryza sativa) }\end{array}$ & Consortia unidentified & FBN, AIA & $\frac{\text { Vanegas \& Uribe }}{2014}$ & $\begin{array}{l}\text { Continuous enrichment in NFB } \\
\text { medium is a good strategy for } \\
\text { the isolation of PGPR on rice } \\
\text { plants. }\end{array}$ \\
\hline Unmentioned & A. chroococcum & $\begin{array}{l}\text { Optimization of culture } \\
\text { medium for production, } \\
\text { FBN, AIA. }\end{array}$ & Gutiérrez et al. 2011 & $\begin{array}{l}\text { Optimizing culture medium } \\
\text { allowing } 150 \% \text { increase in } \\
\text { biomass production. }\end{array}$ \\
\hline
\end{tabular}

Moreno \& Galvis (2013) performed an experiment in maize plants testing the effects of inoculation on $A$. vinelandii ATCC 9046 and six isolates of native microorganisms compared with chemical fertilization treatment, and treatment without fertilization. They found that the the inoculated corns plants with Stenotrophomonas maltophilia showed better results compared with the control and in chemical fertilization variables such as: emergence, diameter and length of the stem and, and dry weight.

In rice, Vanegas \& Uribe (2014) reported that 72 microbial consortia analyzed increased, $41.7 \%$ noted the nitrogenase activity increased, and $50 \%$ the production of indole compounds showed an increase in plant growth promoting activity. Mendoza \& Bonilla (2014) mention that the direct relation between biological nitrogen fixation $(\mathrm{BNF})$ and the photosynthesis process improved the productivity and profitability per hectare of cowpea through the mutual relationship between rhizobia and legumes.

One of the most used techniques to measure the indirect benefits of hormones for plant used by the authors were the quantification of indole-3-acetic acid (IAA-indole acetic acid) that is consistent with reports by Spaepen et al. (2007) and mentioned that it is the quantified and more common in the scientific literature activity. Obando et al. (2010) found that a strain of Azotobacter vinelandii presumptively had the capacity to produce $49.57 \mathrm{~g}$ AIA / ml, compared with the control strains Sp7 (40.17 g AIA / ml) and AC1 (38.26 g AIA / ml) because of its potential activity in promoting plant growth was selected to develop tests at the level of emissions. 
Another activity that was evaluated in the found articles was the synthesis of a range of different antibiotics associated with the ability of bacteria to prevent the growth of pathogens in plant. In spite of the specificity and mode of action studied in detail around the world, it was not a topic frequently investigated in Colombia. This topic was only found in one of the publications, Cuadrado et al. (2009), who reported that fast-growing rhizobia are inherently more sensitive to streptomycin than slow growth; the resistant to gentamicin and amikacin confers an advantage on the strains of rapid growth versus slow growth.

\section{Analysis of co-occurrence}

The obtained results suggest an important dynamic in the field of study; this type of structure is very complex and has central, peripheral, and diverse levels of development (Figure 2). For example, quadrant 1 shows highly specialized topics in the country and which Colombian researchers have had a high impact. In this quadrant, several kinds of microorganisms occur, such as Azotobacter sp. and Bradyrbizobium sp. Several plant species have become part of the research due to its inclusion to keywords in quadrant 1. In addition, there were more keywords associated: salt stress and sustainable agriculture; and later added, bio-fertilizer and biological control.

It is important that the term "sustainable agriculture" is in the first quadrant because, internationally, it has been recognized as the practice in which organic farming is based and considered one of the tools for sustainable development and poverty reduction in developing countries (Martínez et al. 2012). This should be done in accordance with the notions of appropriate land use and its feasibility based on objective welfare, quality of life, and environmental assessment.

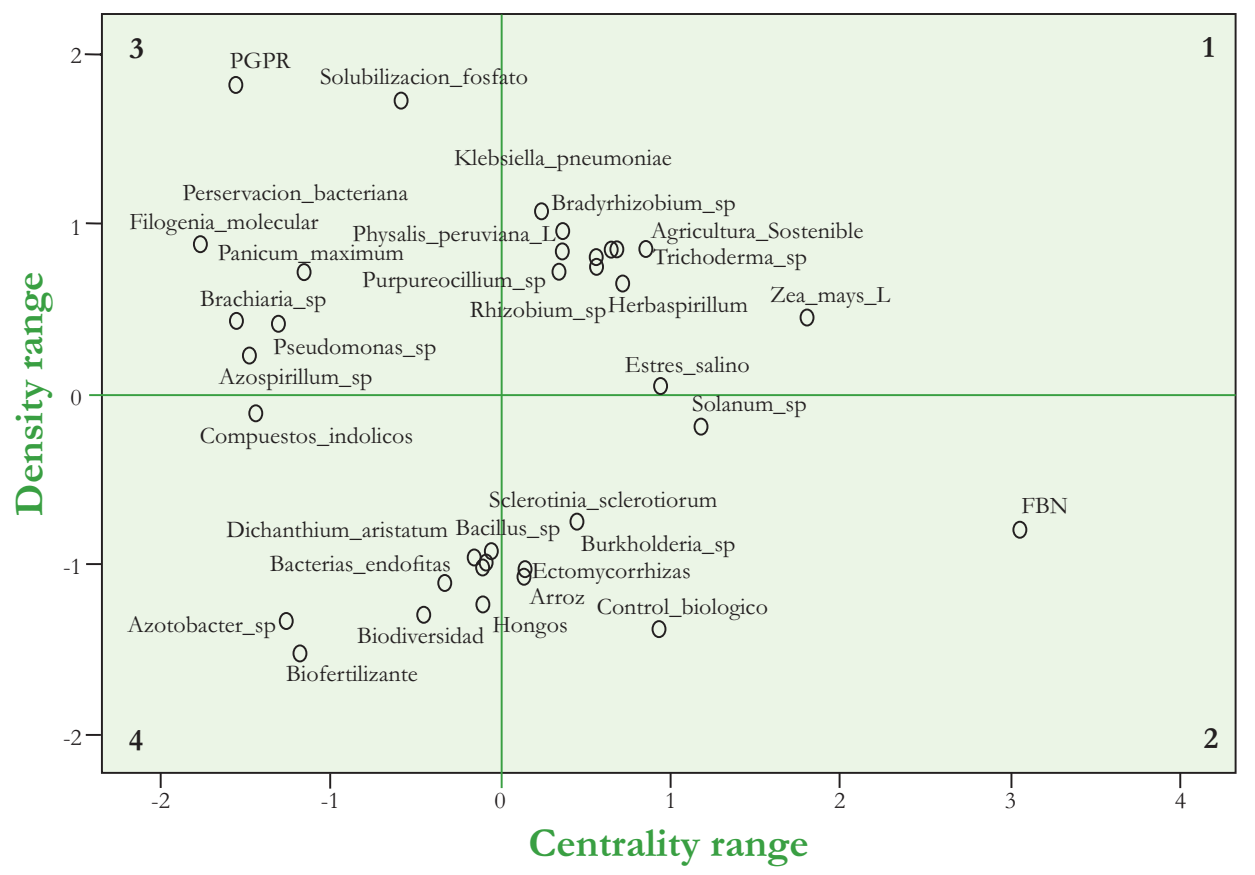

Fig. 2. Quadrant 1: the topics are characterized by main issues and high development. Quadrant 2: Presents the topics considered well-connected but underdeveloped. Quadrant 3: the topics are considered as representative of a highly specialized with a high activity. And quadrant 4: the topics that appeared for the first time and in many cases disappear. 
Quadrant 2 shows highly specialized topics in the country and where the Colombian researchers have a weak impact. These topics could become promising subjects. Quadrant 3 shows the specialized topics that have established methodologies for their research, but they are issues of the other fields and have dabbled in a complementary manner on the issue of bio-products.In these, we found that PGPR was a specialized topic because of its integral part in biofertilizers; bacterial preservation is critical to maintaining the genertic stability of developed products. Finally, molecular phlogeny was used to have comfirmation at the molecular level of genus and specied of microorganisms, allowing subsequently ensure their identity. In these, we found PGPR, an integral type of bio-fertilizers; bacterial preservation is critical to maintaining the genetic stability of the developed products; molecular phylogeny for confirmation at the molecular level of genus and species of microorganism, allowing subsequently maintaining their identity

PGPR are bacteria that may be free or associative life, aerobic, anaerobic or facultative bacteria that produce hormones, vitamins, and growth factors that enhance plant growth and increase the anaerobic plant performance. In Colombia, it was identified that have conducted research related to solubilization of phosphates, nitrogen fixation and production of auxin. According to Malus et al. (2012), future advancements in the PGPR selection should be aimed at improving abiotic stress on crops, namely, tolerance to drought, salinity, inorganic and organic contaminants. In Colombia, it became clear that some investigations are focusing on these areas of interest. For example, Cárdenas et al. (2010) reported that the population of Azospirillum tolerates water stress, and Rojas et al. (2012) mention the bacteria improved resistance to salt stress in corn plant caused by high levels of $\mathrm{NaCl}$ in the soil.

Quadrant 3 shows the specialized topics that have established methodologies for their research, but relate to issues of other fields and have dabbled in a complementary manner on the issue of bio-products. An important issue is the biological nitrogen fixation (FBN) which is presented as a cross-cutting issue in the developed research. Likewise, the presence of topics associated with biological control research and development in ectomycorrhizas were observed. The use of FBN in agricultural crops is done through some rhizosphere bacteria that have the ability to fix N2 in organic form, and supply this at the plants. These bacteria can be in a symbiotic or nonsymbiotic relation with the plant. Legumes form symbiosis with Rhizobium or related genera and the inoculation of these bacteria is made to improve plant establishment. In this study, we found the use of these bacteria in cowpea (Cuadrado et al. 2009), soybean (Valencia \& Ligarreto 2010, Moreno et al. 2014), and quickstick (Cubillos et al. 2011). In the case of non-leguminous plants, there is no symbiotic relation, therefore the plant is inoculate with free-living N2 fixing bacteria, such as Azotobacter and Azospirillium. These were inoculated in patula pine (Orozco \& Martínez, 2009), pastures (Garrido et al. 2010, Cárdenas et al. 2010, Cárdenas et al. 2014), stevia (Borda et al. 2011), vegetables (Jiménez et al. 2011), eucalyptus (Obando et al. 2010, Rojas et al. 2013), and maize (Rojas et al. 2012). In high efficiency plants having photosynthesis (C4 plants) sugar cane and corn, successful results have been obtained when inoculated into the rhizosphere.

Quadrant 4 shows low specialization in the country, but these topics contained are growing in research; for example, endophytic bacteria and biodiversity. The endophytic 
bacteria are recognized as organisms residing in plant tissues: mainly intercellular spaces, rarely in intracellular spaces, and within vascular tissues without causing disease symptoms in the plant, according to Perez et al. (2010) Despite the importance of this type of bacteria, this study showed lack of published papers in Colombia on topics such as the presence of endophytic bacteria, diversity, and productivity in relation to agro-ecosystems in different parts of the country.

\section{Conclusions}

This study was based in the analysis of scientific and technology publications produced by Colombian researchers about the bio-inoculants issue in the period between 2009 and 2014. It was performed to identify the characteristics of main target crops, microorganisms used, and the beneficial effects on agriculture of the bio inculants by the analysis of scientific literature.

In Colombia, there have been advances in research in bio-inoculants, especially PGPR; showing that this issue is known by researchers and developed with established methodologies. This allows them to work in a laboratory, greenhouse and field experiments for the and development bio-inoculants efficiently and of good quality. PGPR issues showed thrust in Columbia, however, requires strategies for successful technology transfer of this biotechnology to producers, to allow potential users to participate in development processes and research.

The results show lack of research on topics that expand the application and efficiency in agriculture, such as consistency between regulators in different countries regarding the requirements and conditions for release into the environment of strains. Additionally, no research has been done on understanding of the advantages and disadvantages of using rhizosphere microorganisms with endophytes, the interactions of them released with native microbiota, and selecting strains of PGPR to function optimally under specific environmental conditions found, as $\mathrm{pH}$, salinity or water stress.

Finally, the results show that Colombian scientific influence on bio-inoculants is barely visible in indexed journals as a worldwide standard. The number of publications found may be limited to achieving intellectual property protection and in many cases protect trade secrets, this situation requires that the patent applications and filings with the ICA these bio-products must be analyzed.

\section{Conflict of interest}

We declare no conflict of interests.

\section{References}

Argüello-Navarro A, Moreno-Rozo L. Evaluación del potencial biofertilizante de bacterias diazotrophas aisladas de suelos con cultivo de cacao (Theobroma cacao L.). Acta Agronómica 63: 238-245, 2014.

doi: $10.15446 /$ acag.v63n3.41033

Baquero I, Tobar M, Campos S, Suárez E, Rosillo A, Sánchez J, Landínez, L. Informe de vigilancia tecnológica. Bioinsumos. Programa Nacional de Biotecnología y Programa Nacional de Ciencias Agropecuarias. Departamento Administrativo de Ciencia, Tecnología e Innovación. Bogotá, Colombia, pp. 145, 2007. 
Bashan Y, Holguin G. Proposal for division of plant growth promoting rhizobacteria into two classifications: biocontrol- PGPB (Plant growth-promoting bacteria) and PGPB, Soil Biology Biochemistry, 30: 1225-1228, 1998.

doi: 10.1016/S0038-0717(97)00187-9

Bashan Y, De Bashan L, Prabhu S, Hernández JP. Advances in plant growth-promoting bacterial inoculant technology: formulations and practical perspectives (1998-2013), Plant and Soil, 378: 1-33, 2014.

doi: 10.1007/s11104-013-1956-x

Beneduzi A, Ambrosini A, Passaglia MP. Plant growth-promoting rhizobacteria (PGPR): Their potential as antagonists and biocontrol agents, Genetics and Molecular Biology, 35: 1044-1051, 2012.

doi: $10.1590 /$ S1415-47572012000600020

Borda-Molina D, Pardo-García JM, Montaña-Lara J, Martínez-Salgado MM. Influencia de la materia orgánica y Azotobacter nigricans en un cultivo de Stevia rebaudiana $\mathrm{B}$, Universitas Scientiarum, 16: 282-293, 2011.

doi: 10.11144/javeriana.SC16-3.ioom

Cárdenas DM, Garrido MF, Bonilla RR, Baldani VLD. Isolation and identification of Azospirillum sp. in Guinea grass (Panicum maximum Jacq.) of the Valle del Cesar, Pastos y forrajes, 33: 1-17, 2010

Cárdenas DM, Garrido MF, Roncallo B, Bonilla RR. Inoculación con Azospirillum spp. y Enterobacter aglomerans en Pasto Guinea (Panicum maximum Jacq.) en el Departamento de Cesar (Colombia), Revista Facultad Nacional de Agronomía Medellín, 67: 7271-7280, 2014. doi: $10.15446 /$ rfnam.v67n2.44168

CCI, Corporación Colombia Internacional. Plan Nacional Hortofruticola. 2012. http://www. asohofrucol.com.co/archivos/biblioteca/biblioteca_28_PHN.pdf. Retrieved 28/08/2015.

Celis C, Moreno G, Sequeda-Castañeda L, Caicedo A, Albarracín D, Barreto L Determining the effectiveness of Candida guilliermondii in the biological control of Rhizopus stolonifer in postharvest tomatoes, Universitas Scientiarum, 19: 51-62, 2014.

doi: 10.11144/Javeriana.SC19-1.debc

Cheng Z, Park E, Glick B. 1-Aminocyclopropane-1-carboxylate deaminase from Pseudomonas putida UW4 facilitates the growth of canola in the presence of salt, Canadian Journal of Microbiology, 53: 912-918, 2007.

doi: 10.1139/W07-050

Cox T, Cox M. Multidimensional Scaling. Boca Ratón, Florida, Ed. Chapman \& Hall. pp. 555, 2001.

Cuadrado B, Rubio G, Santos W. Characterization of Rbizobium and Bradyrbizobium's strains (with ability of nodulation) selected from bean (Vigna unguiculata) cultures as a potentials bioinoculants, Revista Colombiana de Ciencias Químico - Farmacéuticas, 38: 78-104, 2009.

Cubillos-Hinojosa JG, Milian-Mindiola PE, Hernández-Mulford JL. Biological nitrogen fixation by Rhizobium sp. native gliricidia (Gliricidia sepium [Jacq.] Kunth ex Walp.) under greenhouse conditions, Agronomía Colombiana, 29: 465-472, 2011a.

Cubillos-Hinojosa JG, Páez -Redondo A, Mejía- Doria L. Evaluation of the Biocontrol Capacity of Trichoderma harzianum Rifai against Fusarium solani (Mart.) Sacc. Associated to the Complex "Dryer" in Passion Fruit Under Greenhouse Conditions, Revista Facultad Nacional de Agronomía Medellin, 64: 5821-5830, 2011b.

Cuevas V, Lagman C, Jr, Cammagay G, Cuevas A. Trichoderma inoculant as disease biocontrol agent for high value crops: potential financial impact, Philippine Journal of Crop Science, 37: 64-75, 2013. 
Dias A, Gomes dos Santos S, Gomes da Silva V, Radl V, Ribeiro G, Gouvea N. Screening of plant growth promoting rhizobacteria for tha development of vegetable crops inoculants, African Journal of Microbiology Research, 7: 2087-2092, 2013.

doi: 10.5897/AJMR12.2258

Dodd IC, Ruiz-Lozano JM. Microbial enhancement of crop resource use efficiency, Current Opinion in Biotechnology, 23: 236-242, 2012.

doi: 10.1016/j.copbio.2011.09.005

Flórez-Zapata N, García JC, Del Portillo P, Restrepo S, Uribe-Velez, D. Composition and function of the microbial community related with the nitrogen cycling on the potato rhizosphere, Acta Biológica Colombiana,18: 449-464, 2013.

Francis I, Holsters M, Vereecke D. The Gram-positive side of plant-microbe interactions, Environmental Microbiology, 12: 1-12, 2010.

doi: 10.1111/j.1462-2920.2009.01989.x

Gallego-Velásquez J, Cardona-Bustos N, Restrepo-Betancur F. Compatibility of the entomopathogenic fungus Purpureocillium sp. cepa UdeA0106 with biocontrollers fungi and plant protection products, used on chrysanthemum crops, Actualidades Biologicas Volumen, 36: 173-187, 2014.

Garrido MF, Cárdenas DM, Bonilla RR, Baldani VLD. Efecto de los factores edafoclimáticos y la especie de pasto en la diversidad de bacterias diazotróficas, Pastosy Forrajes, 33: 1-11, 2010.

Godfray H, Beddington J, Crute I, Haddad L, Lawrence D, Muir J, Pretty J, Robinson S, Thomas S, Toulmin C. Food Security: The Challenge of Feeding 9 Billion People, Science, 327: 812-818, 2010.

doi: $10.1126 /$ science. 1185383

Gutiérrez-Rojas I, Torres-Geraldo AB, Moreno-Sarmiento N. Optimising carbon and nitrogen sources for Azotobacter chroococcum growth, African Journal of Biotechnology, 15: 2951-2958, 2011.

doi: $10.5897 /$ AJB10.1484

Guzmán A, Obando M, Rivera D, Bonilla RR. Selection and characterization of plant growth promoting rhizobacteria (PGPR's) associated with cotton crop (Gossypium birsutum), Revista Colombiana de Biotecnología, 14: 182-190, 2012.

Hatfield JL, Boote KJ, Kimball BA, Ziska LH, Izaurralde RC, Ortr D, Thomson AM, Wolfe D. Climate impacts on agriculture: Implications for crop production, Agronomy Journal, 103: 351-370, 2011.

doi: 10.2134 /agronj2010.0303

Hayat R Ali S, Amara U, Khalid R, Ahmed I. Soil beneficial bacteria and their role in plant growth promotion: a review, Annals of Microbiology, 60: 579-598, 2010.

doi: 10.1007/s13213-010-0117-1

Insuasty C, Acosta J, Salazar C, Betancourth C. Evaluation of Trichoderma spp. strains for control yellowing pea caused by Fusarium oxysporum, Revista Corpoica Ciencia y Tecnología Agropecuaria, 15: 237-249, 2014.

Jaimes Y, Moreno C, Cotes A. Induced Systemic Resistance Against Fusarium oxysporum In Tomato By Trichoderma koningiopsis Th003, Acta Biológica Colombiana, 14: 111-120, 2009.

Jiménez DJ, Montana JS, Martinez MM. Characterization of free nitrogen fixing bacteria of the genus Azotobacter in organic vegetable-grown Colombian soils, Brazilian Journal of Microbiology, 42: 846-858, 2011. doi: $10.1590 /$ S1517-83822011000300003

Kelemu S, Fory P, Zuleta C, Ricaurte J, Rao I, Lascano C. Detecting bacterial endophytes in tropical grasses of the Brachiaria genus and determining their role in improving plant growth, African Journal of Biotechnology, 10: 965-976, 2011.

doi: $10.5897 /$ AJB10.1305 
Longar M, Ríos E. Análisis cienciométrico sobre el estado del arte de la hidroponía. Caso México, Revista del CIECAS-IPN, 34: 63-74, 2014.

Malus E, Sas-Paszt L, Ciesielska J. Technologies for beneficial Microorganisms Inocula Used as Biofertilizers, The ScientificWorld Journal, Article ID 491206.

doi: $10.1100 / 2012 / 491206$

Malusá E, Vassiley N. A contribution to set a legal framework for biofertiliser, Applied Microbiology and Biotecbnology, 98: 6599-6607, 2014.

doi: 10.1007/s00253-014-5828-y

Martínez L, Bello P, Castellanos O. Sostenibilidad y Desarrollo: el valor agregado de la agricultura orgánica, Universidad Nacional de Colombia, Bogotá, Colombia, pp. 239, 2012.

Medina W, Ramírez J, Sigarroa A. Effect of native strains Paecilomyces sp. (Bainier) and Lecanicillium sp. (Zimm) on the control of Carmenta foraseminis Eichlin (Lepidoptera: Sesiidae) on cocoa (Theobroma cacao L.) crops, Acta Agronómica, 62: 279-286, 2013.

Mendoza J, Bonilla RR. Infectividad y efectividad de rizobios aislados de suelos de la Costa Caribe colombiana en Vigna unguiculata, Revista Colombiana de Biotecnologia, 16: 84-89, 2014.

doi: 10.15446/rev.colomb.biote.v16n2.47246

Moreno L, Galvis F. Biofertilizer potential of diazotrophic bacteria isolated from samples of rhizospheric soil, Pastos y Forrajes, 36: 33-37, 2013.

Moreno LM, Pérez A, Ramírez M, Franco M. Efecto de la temperatura de almacenamiento sobre la viabilidad de bacterias simbióticas fijadoras de nitrógeno utilizadas en la elaboración de inoculantes biológicos para arveja (Pisum sativum) y soya (Glycine max), Revista Colombiana de Biotecnología, 16: 45-56, 2014.

doi: $10.15446 /$ rev.colomb.biote.v16n2.47244

Obando DM, Burgos L, Rivera D, Rubiano MF, Baldani VLD, Bonilla RR. Caracterización de bacterias diazotróficas asimbióticas asociadas al Eucalipto (Eucalyptus sp.) en Codazzi, Cesar (Colombia), Acta Biológica Colombiana, 15: 107-120, 2010.

doi: 10.1111/j.1574-6976.2000.tb00552.x

Orozco-Jaramillo C, Martínez-Nieto P. Evaluación de la inoculación con microorganismos fijadores de nitrógeno asimbióticos aislados de la rizósfera de Pinus patula en Colombia, Bosque, 30: 70-77, 2009. doi: 10.4067/S0717-92002009000200002

Parsa S, Ortiz V, Vega F. Establishing Fungal Entomopathogens as Endophytes: Towards Endophytic Biological Control, Journal of Visualized Experiments, 74: e50360, 2013. doi: $10.3791 / 50360$

Pelc F. Mapa del conocimiento: una herramienta para la gestión tecnológica. In: Manual de Gestión Tecnológica, Cap. 13, Ed. Mc Graw-Hill, Madrid, España. 2000.

Pérez-Andrés C, Estrada-Lorenzo J.M, Villar-Álvarez F, Rebollo-Rodríguez M.J. Estudio bibliométrico de los artículos originales de la Revista Española de Salud Pública (1991-2000). Parte primera: Indicadores generales, Revista Española de Salud Pública, 76: 659-672, 2002.

Pérez A, Rojas J, Fuentes J. Diversidad de bacterias endófitas asociadas a raíces del pasto colosuana (Botbriocbloa pertusa) en tres localidades del Departamento de Sucre, Colombia, Acta Biológica Colombiana, 15: 219-228, 2010.

Ramirez L, Ramirez N, Fuentes L, Jiménez J, Hernández J. Standardising a bioassay for the preliminary evaluation of three commercial Bacillus thuringiensis formulations against Tuta absoluta (Meyrick) (Lepidoptera: Gelechiidae), Revista Colombiana de Biotecnología, 12: 12-21, 2010. 
Rojas-Tapias D, Moreno-Galvan A, Pardo-Diaz S, Obando M, Rivera D, Bonilla R. Effect of inoculation with plant growth-promoting bacteria (PGPB) on amelioration of saline stress in maize (Zea mays), Applied Soil Ecology, 61: 264-272, 2012.

doi: 10.1016/j.apsoil.2012.01.006

Rojas-Tapias D, Ortiz-Vera M, Rivera D, Kloepper J, Bonilla RR. Evaluation of three methods for preservation of Azotobacter chroococcum and Azotobacter vinelandii, Universitas Scientiarum, 18: 129-139, 2013.

doi: 10.11144/Javeriana.SC18-2.etmp

Rueda-Clausen CF, Villa-Roel C, Rueda-Clausen, CE. Indicadores bibliométricos: origen, aplicación, contradicción y nuevas propuestas, MedUNAB, 8: 29-36, 2005.

Sánchez DB, García AM, Romero F, Bonilla RR. Effect of plant growth promoting rhizobacteria phosate solubilizing Lactuca sativa cultivar White Boston, Revista Colombiana de Biotecnología, 16: 122-128, 2014a.

doi: 10.15446/rev.colomb.biote.v16n2.41077

Sánchez DB, Romero FA, Bonilla RR. Physalis perwivana L. response to inoculation with phosphorus solubilizing bacteria, Revista Mexicana de Ciencias Agricolas, 5: 901-906, 2014b.

Sanjuán J, Moreno N. Aplicación de insumos biológicos: una oportunidad para la agricultura sostenible y amigable con el medioambiente, Revista Colombiana de Biotecnología, 12: 4-7, 2010. doi: $10.4236 /$ as.2013.412097

Simbaqueba J, Cotes AM, Barrero LS. Linkage mapping of candidate genes for induce resistance and growth promotion by Trichoderma koningiopsis (Th003) in tomato Solanum lycopersicum, Acta Biologica Colombiana, 16: 47-62, 2011.

Smith A, Beltran CA, Kusunoki M, Cotes AM, Motohashi K, Kondo T, Deguchi M. Diversity of soil-dwelling Trichoderma in Colombia and their potential as biocontrol agents against the phytopathogenic fungus Sclerotinia sclerotiorum (Lib.) de Bary, Journal General Plant Pathology, 79: 74-85, 2013.

doi: 10.1007/s10327-012-0419-1

Solleiro JL, Castañón R, Vega R. Manual Inteligencia Tecnológica Competitiva, Cambio Tec. 2002. http://gtsandyrc.wikispaces.com/file/view/manual+de+inteligencia+tecnologica. pdf. Retrieved 08/05/2015.

Spaepen S, Vanderleyden J, Remans R. Indole-3-acetic acid in microbial and microorganismplant signaling, FEMS Microbiology Reviews, 31: 425-448, 2007. doi: 10.1111/j.1574-6976.2007.00072.x

Téllez J, Morales-Buenrostro L, Estañol B. Análisis del factor de impacto de las revistas científicas latinoamericanas, Revista Médica de Chile, 135: 480-487, 2007. doi: 10.4067/S0034-98872007000400010

Tikhonovich IA, Provorov NA. Microbiology is the basis of sustainable agriculture: an opinion, Annals of Applied Biology, 159: 155-168, 2011. doi: 10.1111/j.1744-7348.2011.00489.x

Valencia RR, Ligarreto MG. Análisis de la interacción soya-cepa (Bradyrbiz̨obium japonicum) x ambiente, en oxisoles de la Orinoquia colombiana, Agronomía Colombiana, 28: 361-371, 2010.

Vanegas J, Uribe-Vélez D. Selection of mixed inoculants exhibiting growth-promoting activity in rice plants from undefined consortia obtained by continuous enrichment, Plant and Soil, 375: 215-227, 2014.

doi: $10.1007 /$ s11104-013-1960-1

Vargas F, Castellanos O. Vigilancia como herramienta de innovación y desarrollo tecnológico. Caso de aplicación: Sector de empaques plásticos flexibles, Revista de Ingeniería e Investigación, 25: 32-41, 2005. 
Vessey JK. Plant growth promoting rhizobacteria as biofertilizers, Plant and Soil, 255: 571-586, 2003.

Villar-Álvarez F, Estrada-Lorenzo JM, Pérez-André C, Rebollo-Rodríguez MJ. Estudio bibliométrico de los artículos originales de la Revista Española de Salud Pública (1991-2000). Parte tercera: análisis de las referencias bibliográficas, Revista Española de Salud Pública, 81: 247-259, 2007.

Análisis cienciométrico de investigación colombiana en bio-inoculantes para producción agrícola

Resumen. El uso excesivo de insumos sintéticos en la producción agrícola ha llevado a la disrupción de los ciclos biogeoquímicos. Como alternativa a este problema, los sistemas de agricultura sostenible han reemplazado parcial o totalmente los químicos por sustancias biológicas. El análisis de literatura científica relevante se ha convertido en una herramienta para determinar la calidad de la generación de conocimiento en este campo y su impacto en el ambiente.Se llevó a cabo un análisis cienciométrico de la investigación en Colombia sobre bioinoculantes entre 2009 y 2014. Se tuvieron en cuenta revistas indizadas en la Red de Ciencias ${ }^{\circledR}$. Se buscó identificar las características de los principales cultivos, los microorganismos utilizados y sus efectos benéficos en la agricultura. Se seleccionaron 34 artículos: 24 (71\%) sobre desarrollo de biofertilizantes y $10(29 \%)$ sobre biopesticidas. Los artículos se enfocaron principalmente en el estudio de bacilos Gram-negativos (77\%), mientras que otros se enfocaron en los temas relativos a hortalizas $(30 \%)$. El análisis de co-ocurrencia de palabras claves identificó: i. Algunos géneros de microorganismos (Azotobacter sp., Bradyrbizobium sp.) y la agricultura sostenible como temas relevantes en este campo, ii. Rizobacterias promotoras del crecimiento en plantas (PGPR) como un tópico emergente, iii. Fijación biológica de nitrógeno (FBN) como un tema emergente y complementario y iv. Bacterias endofíticas y biodiversidad como tópicos en crecimiento. Este estudio mostró también que la investigación en Colombia podría enfocarse en temas como bacterias endofíticas, diversidad y productividad.

Palabras clave: Bioinoculantes; cienciometría; inoculantes microbianos; desarrollo sostenible.

Análise cientométrica das pesquisas colombianas em bioinoculantes para a produçáo agrícola

Resumo. O uso excessivo de produtos químicos sintéticos na produção agrícola levou a uma perturbação dos ciclos biogeoquímicos. Uma das alternativas que surgiram dentro dos sistemas de agricultura sustentável foi a substituição total ou parcial de compostos químicos por substancias biológicas. O estudo de literatura científica relevante se tornou uma ferramenta para avaliar a qualidade da geração de conhecimento e seu impacto no meio ambiente. A análise cientométrica foi realizada em investigações colombianas sobre bioinoculantes de 2009 a 2014, em revistas disponíveis em Web of Science ${ }^{\mathrm{TM}}$, com o intuito de identificar as características das principais culturas alvos, os microorganismos utilizados, e o efeito benéfico na agricultura. Neste trabalho, 34 artigos foram identificados: 24 (71 \%) eram pesquisas sobre o desenvolvimento de biofertilizantes e $10(29 \%)$ sobre biopesticidas. Os artigos eram focados principalmente no estudo de bacilos Gram-negativos afetando a área (77\%), enquanto que outros eram voltados a questões e temas de vegetais $(30 \%)$. A análise de coocorrência de palavras-chave identificou: i. diversos gêneros de microorganismos (Ex. Azotobacter sp., Bradyrbizobium sp.) e agricultura sustentável como questões fundamentais nesta área científica, ii. rizobactéricas promotoras de crescimento de plantas (PGPR) como um tema emergente, iii. fixação biológica de nitrogênio (BNF) como um assunto que tem surgido de maneira complementar e iv. bactérias endofíticas e biodiversidade como temas em crescimento. Este estudo mostrou que a pesquisa na Colômbia poderia ser dirigida a questões como bactérias endofíticas, diversidade e produtividade.

Palavras-chave: Bioinoculantes, cientometria; inoculantes microbianos; desenvolvimento sustentável. 


\section{Diana Corina Zambrano-Moreno}

Industrial Microbiologist, M.Sc. in Design and Process Management in Biosystems. Doctoral Candidate in Natural Sciences for Development at Costa Rica Institute of Technology. She has worked at various organizations like the Colombian Corporation for Agricultural Research (CORPOICA), the Inter-American Institute for Cooperation on Agriculture (IICA) and the Administrative Department of Science and Technology (Colciencias). She has developed programs and projects related to agricultural research, technological development, innovation and technology transfer.

Laura Avellaneda-Franco

Laura holds a B.Sc, in Chemical Engineer and a B.Sc. in Microbiology. She is a M.Sc. in Biological Sciences at Los Andes University. Currently, she works as a researcher at the Colombian Corporation for the Agricultural and Livestock Research. She uses molecular techniques to understand the role of bacteria on plant's health. She is interested on new branches of biotechnology such as synthetic and systems biology.

\section{Gregorio Zambrano Moreno}

Economist, candidate for the degree of M. Sc. in Economics at Universidad Externado de Colombia.

Ruth Rebeca Bonilla-Buitrago

Doctor in Agricultural Science, Warsaw Agricultural University. Researcher at Corporación Colombiana de Investigación Agropecuaria. She leads the research group "Sustainable Agricultural and Livestock Systems". Her research focus on the use of biofertilizers to enhance the yield of Colombian crops. As a national reference in topics related to plant growth promoting bacteria she has directed national and international projects in those fields. She is catalogued as a Senior Researcher by Colciencias. 